\title{
Pengaruh Teknik Relaksasi Terhadap Penurunan Nyeri Epigastrium Pada Pasien Gastritis
}

\author{
Nuryanti Erni ${ }^{1}$, Abidin M Zainal ${ }^{2}$, Normawati Ajeng Titah ${ }^{3}$ \\ 1,2,3 Prodi D-III Keperawatan Blora, Poltekkes Kemenkes Semarang, Indonesia
}

*Corresponding author : Erni Nuryanti

Email: erninuryanti@gmail.com

Received: March 9, 2020; Accepted: March 20, 2020, Published : March 31, 2020

\begin{abstract}
Background: Today the frequency of psychosomatic illnesses experienced by a person is increasing. One such psychosomatic disease is gastritis. Pharmacotherapy for gastritis often results in less satisfactory results. Meanwhile the other alternatives to overcome these problems can be done with relaxation exercises. Relaxation can increase the sensitivity of baro-reflect and decrease sympathetic nerve activity and activate the correction so that there will be a decrease of pain level.

Objective: To know the effect of relaxation technique on the reduction of epigastria pain in gastritis patients. Research Method: The design of the research used is one group pre test and post test design, where the patient came to check the level of pain with the scale of pain then done relaxation. After the relaxation was done and then re-check in the same way. Bivariate analysis used Wilcoxon Test.

Results: The statistical results obtained $p=0,000(\mathrm{P}<0.05)$ which means that there is a very significant difference in the average value of the pain scale before relaxation with the average of pain scale after relaxation.
\end{abstract}

Conclusion: There is a relaxation effect on the reduction of epigastria pain in gastritis patients

Keyword: Relaxation, Pain, Epigastria

\section{Pendahuluan}

Gastritis merupakan penyakit yang sering dialami oleh seseorang.Gastritis atau yang lebih dikenal sebagai maag yang berasal dari bahasaYunani yaitu gastro yang berarti perut /lambung dan itis yang berarti peradangan atau inflamasi. Pasien yang mengalami gastritis menyebabkan tidak dapat melakukan kegiatan sehari-hari secara normal (Hawari,2013).

Gejala yang umum terjadi pada penderita gastritis adalah rasa tak nyaman (nyeri) pada epigastrium, perut kembung, sakit kepala dan mual yang dapat mengganggu aktifitas sehari-hari. Dampak fisiologis pada nyeri epigastrium menyebabkan munculnya stimulasi simpatik berupa dilatasi saluran bronchial, peningkatan respirasi rate, peningkatan heart rate, vasokontriksi perifer, peningkatan tekanan darah, peningkatan nilai gula darah, diaphoresis, peningkatan kekuatan otot, dilatasi pupil. Sedangkan pada nyeri berat banyak ditemukan stimulasi para simpatik (nyeri berat dan dalam) seperti muka pucat, otot mengeras, penurunan heart rate dan tekanan darah, nafas cepat dan irreguler, nausea, vomitus, kelelahan dan keletihan (Potter \& Perry, 2009).

Menurut data yang diperoleh dari Dinas Kesehatan Kabupaten Blora penyakit gastritis merupakan urutan daftar 3 penyakit yang paling sering dikeluhkan pasien, tahun 2015 tercatat data terakhir bulan Agustus sebanyak 125 pasien dan bulan September meningkat menjadi 155 pasien (DKK Blora, 2015). Berdasarkan studi pendahuluan yang dilakukan peneliti di RSUD dr R Soetijono Blora data tentang jumlah pasien gastritis yang didapatkan peneliti di rekam medis mengalami peningkatan yaitu tahun 2012 sebanyak 155 orang, tahun 2013 sebanyak 172 orang, tahun 2014 sebanyak 198 orang,data tiga bulan terakhir tahun 2016 di Ruang Dahlia menunjukkan pada bulan September jumlah pasien gastritis sebanyak 28 orang, pada bulan Oktober sebanyak 30 orang sedangkan pada bulan November sebanyak 33 orang.

Hasil wawancara awal dengan perawat di ruangan ternyata untuk penatalaksanaan gastritis dengan keluhan mual-muntah, anoreksia, nyeri epigastrium lebih sering dengan penggunaan secara farmakologi.Penggunaan obat farmakologi dalam 
buku DOI (Daftar Obat Indonesia) dan ISO serta hasil wawancara sebagai studi pendahuluan dengan perawat jaga Ruang Dahlia RSUD dr SoetijonoBlora, menyebutkan obat - obatan yang sering dipakai untuk mengobati penderita gastritis adalah Ranitidin,Cimetidin, dan Ulsikur.

Sutrisno (2012) mengatakan bahwa farmakoterapi terhadap gastritis sering menimbulkan hasil kurang memuaskan.Sedangkan alternatif lain untuk mengatasi masalah tersebut dari sisi keperawatan dapat dilakukan dengan latihan relaksasi progresif. Namun berdasarkan pengalaman peneliti setelah dilakukan pendekatan di rumah sakit terbukti teknik relaksasi belum banyak dilakukan,bahkan sangat jarang dilakukan khususnya untuk mengurangikeluhan nyeri epigastrium pada penderita gastritis.Menurut (Evi Lina Sutrisno, 1998) teknik relaksasi progresif ini telah diketahui efektif menurunkan gejala fisik pada pasien gastritis dan ulkus peptikum. Penelitian Chappel, Stefano dan Rogerson (1992) menggunakan pelatihan relaksasi terhadap pasien gastritis dan ulkus peptikum dengan menurunkan intensitas kekambuhan.

Teknik relaksasi sangat berperan dalam mengurangi keluhan fisik dan meminimalkan efek efek dari stres, sehingga memungkinkan pasien dapat mengontrol tubuh merespon ketegangan dan kecemasan sehingga dapat menurunkan produksi asam lambung (KazierdanErb,2008). Menurut Gunawan (2001) mengatakan bahwa relaksasi berguna mengurangi stres atau ketegangan jiwa yang merupakan salah satu cara untuk mencegah dan menurunkan rasa nyeri. Relaksasi dapat meningkatkan sensitifitas baroreflek dan menurunkan aktifitas syaraf simpatis dan mengaktifasi kemoreflek sehingga menawarkan efek pada penurunan tingkat nyeri. Dengan tindakan relaksasi diharapkan nyeri pada epigastrium akan menurun. Tindakan relaksasi yang mudah dilakukan untuk mengatasi rasa nyeri tersebut adalah dengan relaksasi. progresif memberikan pengaruh yang paling baik untuk jangka waktu yang relatif singkat dalam mengatasi nyeri pada pasien gastritis.

Berdasarkan hasil studi pendahuluan pada 7 penderita gastritis, 5 orang mengatakan bahwa setelah diberikan tindakan relaksasi progresif nyeri epigastriumnyanya berkurang tanpa mereka diberi obat.

Dari fenomena ini peneliti tertarik ingin melakukan penelitian "Pengaruh tehnik relaksasi terhadap penurunan nyeri epigastrium pada pasien gastritis di RSUD dr Soetijono Blora".

\section{Metode Penelitian}

Desain penelitian yang digunakan adalah dengan metode one group pre test and post test design, dimana pasien datang dilakukan pengecekan tingkat nyeri dengan skala nyeri lalu dilakukan relaksasi. Setelah dilakukan relaksasi dilakukan pengecekan ulang dengan cara yang sama. Penelitian ini melakukan intervensi terhadap responden berupa relaksasi untuk menurunkan nyeri epigastrium pada pasien gastritis, sampel yang dipilih secara total sampling terhadap pasien gastritis yang dirawat di RSUD dr R Soetijono Blora. Data diolah dan dianalisa dengan analisis univariat dan bivariat. Analisis bivariat ini dilakukan untuk menguji hipotesis pengaruh antara variable independen dengan variable dependen. Uji statistik yang digunakan dengan menggunakan uji Paired Sample T-Test.

\section{Hasil dan Pembahasan}

\section{Hasil}

Tabel 1 Distribusi pasien gastritis berdasarkan usia di RSUD dr R Soetijono Blora tahun $2017(n=30)$

\begin{tabular}{lcc}
\hline Jenis kelamin & $\begin{array}{c}\text { Frekuensi } \\
(\mathrm{n})\end{array}$ & $\begin{array}{c}\text { Persentase } \\
(\%)\end{array}$ \\
\hline$<20$ & 2 & 6.7 \\
\hline $20-40$ & 11 & 36.7 \\
\hline $41-60$ & 14 & 46.7 \\
\hline$>60$ & 3 & 10.0 \\
\hline Total & 30 & 100.0 \\
\hline
\end{tabular}

Pada tabel 1 menunjukkan bahwa jumlah tertinggi dari responden dengan gastritis adalah berusia 41-60 yaitu sejumlah 14 (46.7\%) sedangkan jumlah terendah dari respondendengan gastritis adalah berusia $<20$ yaitu sejumlah 2 (6.7\%).

Tabel 2. Distribusi pasien gastritis berdasarkan jenis kelamin di RSUD dr R Soetijono Blora tahun $2017(\mathrm{n}=30)$

\begin{tabular}{ccc}
\hline $\begin{array}{c}\text { Jenis } \\
\text { kelamin }\end{array}$ & $\begin{array}{c}\text { Frekuensi } \\
(\mathrm{n})\end{array}$ & $\begin{array}{c}\text { Persentase } \\
(\%)\end{array}$ \\
\hline Laki-laki & 21 & 70 \\
Perempuan & 9 & 30 \\
\hline Jumlah & 32 & 100 \\
\hline
\end{tabular}

Pada tabel 5.2 menunjukkan bahwa jumlah tertinggi dari responden dengan gastritisa dalah berjenis kelamin laki-laki yaitu sebanyak 21(70\%) sedangkan selebihnya berjenis kelamin sejumlah 9 $(30 \%)$. 
Tabel 3. Distribusi pasien gastritis berdasarkan status pernikahan di RSUD dr R Soetijono Blora tahun $2017(n=30)$

\begin{tabular}{lcc}
\hline $\begin{array}{c}\text { Status } \\
\text { pernikahan }\end{array}$ & $\begin{array}{c}\text { Frekuensi } \\
(\mathrm{n})\end{array}$ & $\begin{array}{c}\text { Persentase } \\
(\%)\end{array}$ \\
\hline Menikah & 26 & 86.7 \\
Belum & 4 & 13.3 \\
menikah & & \\
\hline \multicolumn{1}{c}{ Jumlah } & 32 & 100
\end{tabular}

Pada tabel 3 menunjukkan bahwa jumlah tertinggi dari responden dengan gastritisadalah berstatus menikah yaitu sebanyak 26 (86.7\%) sedangkan selebihnya berstatus belum menikah sejumlah 4 (13.3\%).

Tabel 4. Distribusi pasien gastritis berdasarkan suku bangsa di RSUD dr R Soetijono Blora tahun $2017(\mathrm{n}=30)$

\begin{tabular}{ccc}
\hline $\begin{array}{c}\text { Suku } \\
\text { bangsa }\end{array}$ & $\begin{array}{c}\text { Frekuensi } \\
(\mathrm{n})\end{array}$ & $\begin{array}{c}\text { Persentase } \\
(\%)\end{array}$ \\
\hline Suku jawa & 30 & 100 \\
Luar jawa & 0 & 0 \\
\hline Jumlah & 32 & 100 \\
\hline
\end{tabular}

Pada tabel 5.4 menunjukkan bahwa seluruh responden dengan gastritismempunyai suku jawa yaitu sebanyak $30(100 \%)$.

Tabel 5 : Hasil pengukuran skala nyeri sebelum relaksasi pasien gastritis di RSUD $\mathrm{dr} R$ Soetijono Blora tahun $2017(\mathrm{n}=30)$

\begin{tabular}{ccc}
\hline Skala nyeri & Frekuensi $(f)$ & Prosentase $(\%)$ \\
\hline 4 (nyeri sedang) & 8 & 26.7 \\
5 (nyeri sedang) & 10 & 33.3 \\
6 (nyeri sedang) & 12 & 40.0 \\
\hline Total & 30 & 100.0 \\
\hline
\end{tabular}

Mean: 5.13

SD : 0.819

Berdasarkan tabel 5 dapat diketahui bahwa distribusi skala nyeri sebelum dilakukan relaksasi yang tertinggi adalah skala nyeri 6 (nyeri sedang) sejumlah 12 responden (40\%), kemudian skala nyeri 5(nyeri sedang) sejumlah 10 responden (33.3\%) dan yang terendah skala nyeri 4 (nyeri sedang) sejumlah 8 responden (26.7\%). Dengan rata-rata skala nyeri 5.13 .

Tabel 6. Hasil pengukuran skala nyeri setelah relaksasi pasien gastritisdi RSUD dr R Soetijono Blora tahun $2017(n=30)$

\begin{tabular}{ccc} 
Skala nyeri & Frekuensi $(f)$ & Prosentase $(\%)$ \\
\hline 1 (nyeri ringan) & 3 & 10.0 \\
2 (nyeri ringan) & 6 & 20.0 \\
3 (nyeri ringan) & 10 & 33.3 \\
4 (nyeri sedang) & 8 & 26.7 \\
5 (nyeri sedang) & 3 & 10.0 \\
\hline Total & 30 & 100.0
\end{tabular}

Mean : 3.07

SD : 1.143

Berdasarkan tabel 6 dapat diketahui bahwa distribusi skala nyeri setelah dilakukan relaksasi progresif yang tertinggi adalah skala nyeri 3 (nyeri ringan) dan skala nyeri 4 (nyeri sedang) sejumlah 9 responden (28.1\%), kemudian skala nyeri 2 (nyeri ringan) sejumlah 7 responden (21.9\%), selanjutnya skala nyeri 1 (nyeri ringan) sejumlah 4 responden (12.5\%) dan yang terendah skala nyeri 5 (nyeri sedang) sejumlah 3responden (9.4\%). Dengan ratarata skala nyeri 3.07 .

\section{Analisis Bivariat}

Sebelum dilakukan uji beda rata-rata antara skala nyeri sebelum dan sesudah dilakukan relaksasi perlu dilakukan uji normalitas skala intensitas nyeri sebelum relaksasi dan sesudah relaksasi dalam dengan uji Shapiro-Wilk, karena jumlah responden kurang dari 50.

Tabel 7. Tabel uji normalitas data

\begin{tabular}{llll}
\hline $\begin{array}{c}\text { Shapiro- } \\
\text { Wilk }\end{array}$ & Statistik & $d f$ & $p$-value \\
\hline Pre-test & 0.720 & 30 & 0.000 \\
Post-test & 0.921 & 30 & 0.029 \\
\hline
\end{tabular}

Dari hasi uji Shapiro-Wilk pada skala nyeri sebelum relaksasi progresif didapatkan nilai $p$-value sebesar $0,000(>0,05)$ yang berarti data berdistribusi tidak normal pada responden. Sedangkan pada responden sesudah dilakukan relaksasi didapatkan $p$-value sebesar $0,029(>0,05)$ yang berarti data berdistribusi tidak normal.

Setelah mengetahui data tidak berdistribusi normal maka uji alternatif yang digunakan adalah uji Wilcoxon dengan cara mengubah data menjadi Ordinal. Dari hasil uji Wilcoxon dengan menggunakan SPSS versi 16.0 terhadap skala intensitas nyeri sebelum dan sesudah mendapat perlakuan relaksasi menunjukkan hasil sebagai berikut :

Table 8. Tabel out put rank perlakuan sebelum dan sesudah relaksasi pada pasien gastritisdi RSUD dr R Soetijono Blora tahun 2017.

\begin{tabular}{llccc}
\hline & & N & $\begin{array}{c}\text { Mean } \\
\text { Rank }\end{array}$ & $\begin{array}{c}\text { Sum of } \\
\text { Ranks }\end{array}$ \\
\hline $\begin{array}{l}\text { Nyeri } \\
\text { setelah } \\
\text { relaksasi } \\
\text { progresif - }\end{array}$ & $\begin{array}{l}\text { Skala nyeri } \\
\text { turun }\end{array}$ & $27^{\mathrm{a}}$ & 14.00 & 378.00 \\
$\begin{array}{l}\text { Nyeri } \\
\text { nebelum } \\
\text { relaksasi } \\
\text { nafas } \\
\text { dalam }\end{array}$ & $\begin{array}{l}\text { Skala nyeri } \\
\text { tetap }\end{array}$ & $0^{\mathrm{b}}$ & .00 & .00 \\
\hline & Total & 30 & & \\
\hline
\end{tabular}

Berdasarkan tabel 8 hasil Output ranks menunjukkan perbandingan skala nyeri sebelum dan 
sesudah relaksasi, terdapat 27 responden dengan hasil skala nyeri setelah relaksasi progresif lebih rendah dari pada sebelum relaksasi, sedangkan 3 responden mempunyai skala nyeri yang sama sebelum dan sesudah relaksasi.

Table 9. Tabel statistik perlakuan sebelum dan sesudah relaksasi pada pasien gastritisdi RSUD dr R SoetijonoBlora tahun 2017.

\begin{tabular}{lr}
\hline & $\begin{array}{c}\text { Nyeri setelah relaksasi } \\
\text { progresif - Nyeri sebelum } \\
\text { relaksasi nafas dalam }\end{array}$ \\
\hline $\mathrm{Z}$ & $-4.589^{\mathrm{a}}$
\end{tabular}

Asymp. Sig. (2tailed)

Berdasarkan tabel 9. Hasil analisis statistik diperoleh hasil $p=0,000(P<0,05)$ yang berarti ada perbedaan yang sangat signifikan nilai rata-rata skala nyeri sebelum relaksasi dengan rata-rata skala nyeri setelah relaksasi, sehingga dapat ditarik kesimpulan bahwa dengan nilai $p=0,000$ maka Ho ditolak dan Ha diterima, yang artinya ada pengaruh penggunaan relaksasi terhadap penurunan tingkat nyeri pada pasien gastritis di RSUD dr R Soetijono Blora.

\section{Pembahasan}

\section{Hasil pengukuran skala nyeri pre relaksasi pada pasien gastritis}

Berdasarkan tabel 5 dapat diketahui bahwa distribusi skala nyeri sebelum dilakukan relaksasi yang tertinggi adalah skala nyeri 6 (nyeri sedang) sejumlah 12 responden (40\%), kemudian skala nyeri 5 (nyeri sedang) sejumlah 10 responden (33.3\%) dan yang terendah skala nyeri 4 (nyeri sedang) sejumlah 8 responden $(26.7 \%)$. Dengan rata-rata skala nyeri 5.13

Terjadinya peradangan akan menimbulkan gejala rubor, kalor dan dolor. Kalor (nyeri) disebabkan akibat terjadinya jaringan yang rusak sehingga suplai oksigen kejaringan menurun. Mekanisme koping terhadap nyeri bagi setiap orang akan berbeda dipengaruhi oleh beberapa faktor diantaranya jenis kelamin, usia dan pengalaman nyeri sebelumnya.

Hal ini sesuai dengan teori yang menyatakan bahwa rasa nyeri timbul bila jaringan yang rusak, yang menyebabkan aliran darah kejaringan dan kulit berkurang (iskemia) sehingga suplai oksigen juga berkurang. Hal ini akan mengakibatkan terkumpulnya sebagian besar asam laktat dalam jaringan, yang terbentuk akibat metabolisme anaerob (metabolisme tanpa oksigen) dan mungkin juga ada bahan-bahan kimiawi lainnya seperti bradikinin dan enzim proteolitik yang terbentuk dalam jaringan akibat kerusakan sel, dan apabila bahan-bahan ini dibandingkan asam laktat akan merangsang ujung serabut syaraf nyeri
(Guyton\&Hall, 1997). Menurut sebuah penelitian di Atlanta for Behavioral Medicine, dikutip dari Sciencedily, temuan ini telah dipresentasikan dalam American Psychological Association di San Diego, peneliti menduga faktor hormonal turut mempengaruhi perbedaan nyeri yang dirasakan lakilaki dan perempuan. Beberapa jenis hormon memang berhubungan sensasi nyeri. Menurut Dr. Jenifer Kelly perbedaan hormonal antara laki-laki dan perempuan menduga turut mempengaruhi respons terhadap nyeri.

\section{Hasil pengukuran skala nyeri setelah relaksasi pada pasien gastritis}

Berdasarkan tabel 6 dapat diketahui bahwa distribusi skala nyeri setelah dilakukan relaksasi yang tertinggi adalah skala nyeri 3 (nyeri ringan) dan skala nyeri 4 (nyeri sedang) sejumlah 9 responden (28.1\%), kemudian skala nyeri 2 (nyeri ringan) sejumlah 7 responden (21.9\%), selanjutnya skala nyeri 1 (nyeri ringan) sejumlah 4 responden $(12.5 \%)$ dan yang terendah skala nyeri 5 (nyeri sedang) sejumlah 3responden (9.4\%). Dengan ratarata skala nyeri 3.07.

Dengan dilakukannya relaksasi menunjukkan adanya kecenderungan penurunan jumlah responden yang mengalami nyeri. Hal ini dikarenakan pemberian tehnik distraksi relaksasi dapat memberikan perubahan signifikan pada penurunan rasa nyeri, penggunaan relaksasi juga dirasakan lebih efektif, sederhana dan pilihan yang tepat disamping terapi medis.

Sedangkan dari hasil Output ranks menunjukkan perbandingan skala nyeri sebelum dan sesudah bimbigan imajinasi, terdapat 27 responden dengan hasil skala nyeri setelah relaksasi progresif lebih rendah daripada sebelum relaksasi, sedangkan 3 responden mempunyai skala nyeri yang sama sebelum dan sesudah relaksasi.

Ketidak berhasilan pemberian tehnik relaksasi dipengaruhi oleh beberapa faktor : dimana saat pelaksanaa tehnik relaksasi lingkungan dalam keadaan tidak tenang. Hal ini sesuai dengan teori yang menyatakan bahwa dalam pelaksanaan relaksasi dipengaruhi berbagai faktor. Berbagai macam faktor yang mempengaruhi diantaranya adalah keadaan lingkungan, ketrampilan dalam pemberian relaksasi, serta faktor dari dalam peneriman tindakan relaksasi (Suryanto, 2009).

Hasil pengukuran skala nyeri pre dan post guide imagery pada pasien gastritis

Dari hasil penelitian menunjukan bahwa terdapat perbedaan yang signifikan terhadap nilai skala nyeri sebelum dan sesudah perlakuan dengan $p$ value sebesar 0,000 $(p<0,05)$. Hal ini sesuai teori bahwa penggunaan relaksasi pada pasien gastritisakan membantu penurunan nilai skala nyeri (Tamsuri, 2006). 
Kurangnya oksigen dalam darah memperbesar kemungkinan terjadinya kecemasan, depresi, lelah karena proses perfusi ke jaringan tubuh terhambat sehingga terjadi metabolisme anaerob. Dengan latihan relaksasi tepat dan teratur akan memperbaiki oksigenasi ke seluruh jaringan tubuh termasuk otak, sehingga fungsi otak sebagai pengendali kecemasan menjadi lebih baik dan tingkat kecemasan dapat diturunkan sehingga keluhan fisik dapat diminimalkan (Davis, 2008).

Secara fisiologis latihan relaksasi akan mengurangi aktivitas saraf simpatis yang mangembalikan tubuh pada keadaan seimbang, pupil, pendengaran, tekanan darah, denyut jantung, pernafasan dan sirkulasi kembali normal dan otototot menjadi relaks. Respon relaksasi merupakan efek penyembuhan yang memberikan kesempatan untuk beristirahat dari stres lingkungan eksternal dan stres lingkungan internal (Davis, 2008). Penurunan rangsang simpatis juga dapat menurunkan motilitas sekretoris dan mendekati normal, selanjutnya asam lambung akan tertahan di sel pariental pada $\mathrm{pH}$ mendekati normal sehingga sekresi asam lambung akan mengalami penurunan dan terjadi penyembuhan luka (Gulton, 1997).

\section{Kesimpulan}

Skala intensitas nyeri pada pasien gastritis sebelum relaksasi terbanyak adalah skala intensitas nyeri 6. Skala intensitas nyeri pada pasien gastritis sesudah relaksasi terbanyak adalah skala intensitas nyeri 3. Ada pengaruh relaksasi terhadap penurunan intensitas nyeri pada pasien gastritis, dimana didapatkan nilai $p 0,000(<0,05)$.

\section{Pustaka}

1. Alimul H, Aziz, (2012), Riset Keperawatan Dan Teknik Penulisan Ilmiah, Edisi I, Jakarta: Salemba Medika.

2. Arikunto, Suharsimi. (2012). Prosedur Penelitian, Suatu Pendekatan Praktek. Edisi Revisi V. Rineka Cipto. Jakarta.

3. Carpenito, L.J., (1999), Rencana Asuhan dan Dokumentasi Keperawatan: Diagnosa Keperawatan dan masalah Kolaboratif, Edisi kedua, EGC, Jakarta.

4. Carpenito, L.J., (2013), Diagnosa Keperawatan: Aplikasi Pada praktek Klinik, Edisi 6, EGC, Jakarta.

5. Dalami, Ernawati dkk, (2012), Asuhan Keperawatan Jiwa Dengan masalah Psikososial, Jakarta: Trans Info Medika.

6. Engram, Barbara, (1999), Rencana Asuhan Keperawatan Medikal bedah, Volume 3, EGC, Jakarta.

7. Hawari, D, ( 2002 ), ManajemenStres, Cemas dan Depresi,Edisi 1, FKUI, Jakarta.
8. Hegner, Barbara R, ( 2013), Asisten Keperawatan: Suatu Pendakatan Proses Keperawatan, Edisi 6, EGC, Jakarta.

9. Jatman, D, ( 2010 ), Psikologi Perkembangan, Badan Penerbit Universitas Diponegoro, Semarang.

10. Kaplan dan Sadock, ( 2010 ), Sinopsis Psikiatri, Bina Rupa Aksara, Jakarta.

11. Kozier B and Oliveri, ( 1991 ), Fundamental of Nursing Concept Process Practice, $4^{\text {th }} \mathrm{ed}$, Wesley, California.

12. Long, B.C., (2013), Perawatan Medikal Bedah (Suatu Pendekatan Proses Keperawatan),Edisikedua, Yayasan Ikatan Alumni Pendidikan Keperawatan Universitas Padjajaran, Bandung.

13. Nursalam, (2013), Konsep dan Penerapan Metodologi Penelitian Ilmu Keperawatan, Pedoman Skripsi, Tesis dan Instrumen Penelitian Keperawatan, Jakarta: Salemba Medika

14. Potter, Patricia A, , (2005), Buku Ajar Fundamental Keperawatan: Konsep, Proses, Dan Praktik,Edisi 4, EGC, Jakarta.

15. Stuart, Gail W, (2011), Buku Saku Keperawatan Jiwa,Edisi 5, EGC, Jakarta.

16. Smeltzer, Suzanne C, (2012), Buku Ajar Keperawatan Medikal Bedah-Brunner \&Suddart, Edisi 8, EGC, Jakarta. 